\title{
VARIASI KOMUNITAS PLANKTON DAN PARAMETER OSEANOGRAFI DI DAERAH PENANGKAPAN IKAN PELAGIS DI PERAIRAN MALANG SELATAN, JAWA TIMUR
}

\author{
Aida Sartimbul $^{a, b^{*}}$, Ardelia Annisa Larasatia ${ }^{a}$ dan Syarifah H. Julinda Sari ${ }^{a, b}$, \\ Erfan Rohadi', Defri Yona ${ }^{\text {a,b }}$ \\ ${ }^{a}$ Fakultas Perikanan dan Ilmu Kelautan, Universitas Brawijaya, Jalan Veteran, Malang, 65145, Indonesia. \\ ${ }^{b}$ Marine Exploration and Management (MEXMA) Research group, Fakultas Perikanan dan Ilmu \\ Kelautan, Universitas Brawijaya, Jalan Veteran, Malang 65145, Indonesia. \\ ${ }^{\mathrm{c}}$ Teknologi Informasi, Politeknik Negeri Malang, Jalan Sukarno Hatta 9, Malang 65141, Indonesia \\ *Corresponding author: aida@ub.ac.id
}

\begin{abstract}
Abstrak
Keberadaan plankton berperan penting dalam kelimpahan sumberdaya perikanan di suatu daerah penangkapan. Minimnya informasi terkait kelimpahan plankton di daerah penangkapan mendorong dilakukannya penelitian ini. Penelitian ini bertujuan untuk mengetahui variasi komunitas plankton dan hubungannya dengan parameter oseanografinya, serta distribusi spasial plankton di daerah penangkapan ikan di Perairan Malang Selatan, Jawa Timur. Metode purposive sampling dengan teknik zigzag pada 10 titik sampling digunakan dalam pengambilan data pada penelitian ini. Sedwicgk rafter counting cell digunakan dalam metode penghitungan plankton. Sampel plankton diambil secara horizontal dan vertikal pada kedalaman 1 dan $15 \mathrm{~m}$ dengan jaring plankton bermata jaring $20 \mu \mathrm{m}$, sedangkan parameter oseanografi secara in situ diukur menggunakan aqua quality sensor tipe AAQ 1183 C. Hasil penelitian menunjukkan bahwa kelimpahan fitoplankton sebesar $49.764 \mathrm{sel} / \mathrm{m} 3$, didominasi oleh genus Chaetoceros. (Bacillariophyceae), dan kelimpahan zooplankton sebesar 894 ind/m3, didominasi oleh genus Nauplius. (Copepoda). Indeks keanekaragaman dan keseragaman fitoplankton dan zooplankton dapat dikategorikan sedang, berturut-turut sebesar $1,77-1,85$ dan $1,70-1,77 ; 0,58-0,59$ dan $0,77-0,79$, sedangkan indeks dominansinya masuk dalam kategori rendah yaitu berturut-turut $0,27-0,28$ dan $0,24-0,27$. Analisis Principal Component Analysis (PCA) menunjukkan bahwa parameter oseanografi utama yang paling berpengaruh pada variasi komunitas plankton adalah turbiditas, klorofil-a, oksigen terlarut dan fosfat. Hasil uji $\mathrm{T}$ menunjukkan bahwa distribusi spasial kelimpahan fitoplankton dan zooplankton pada kedalaman $1 \mathrm{~m}$ dan $15 \mathrm{~m}$ berbeda nyata. Studi ini memberikan informasi penting tentang kelimpahan plankton dan faktor oseanografi yang berpengaruh di daerah penangkapan di Perairan Malang Selatan.
\end{abstract}

Kata Kunci: fishing ground, komunitas plankton, parameter oseanografi, Perairan Malang Selatan

\begin{abstract}
The existence of plankton plays an important role in the abundance of fishery resources in a fishing area. The lack of information related to the abundance of plankton in the fishing grounds encouraged this study.This study aims to determine the variation of the plankton community and its relationship to oceanographic parameters, as well as the spatial distribution of plankton in the fishing ground of South Malang water. The purposive sampling method with zigzag technique at 10 sampling sites was used in data collection. Sedwicgk rafter counting cells were used in plankton counting methods. The plankton samples were taken horizontally and vertically at 1 and $15 \mathrm{~m}$ depth by $20 \mu \mathrm{m}$ meshsize planktonnet, while in situ oceanographic parameters were collected by aqua quality sensor AAQ-1183C. The results showed that phytoplankton abundance was 49.764 cells $/ \mathrm{m}^{3}$, dominated by Chaetoceros (Bacillariophyceae), and zooplankton abundance of $894 \mathrm{ind} / \mathrm{m}^{3}$, dominated by Nauplius (Copepoda). The diversity and similarity index of phytoplankton and zooplankton are categorized as medium as 1.77-1.85 and 1.70-1.77; 0.58-0.59 and 0.77-0.79, respectively, while the dominance index was categorized as low as $0.27-0.28$ and $0.24-0,27$, respectively. Principal Component Analysis (PCA) analysis showed that the most important major oceanographic parameters for plankton community variation were turbidity, chlorophyll-a, dissolved oxygen and phosphate. T-test results show that the spatial distribution of phytoplankton abundance and zooplankton at depth of $1 \mathrm{~m}$ and $15 \mathrm{~m}$ are significantly different. This study provides important information on the plankton abundance and oceanography factors affected at fishing ground of South Malang water.
\end{abstract}

Keywords: fishing ground, oceanography parameters, plankton community, South Malang Water 


\section{PENDAHULUAN}

Perairan Malang Selatan merupakan bagian dari perairan selatan Jawa yang berbatasan langsung dengan Samudera Hindia dan sangat potensial sebagai daerah penangkapan ikan [1]. Daerah penangkapan ikan merupakan suatu perairan dimana faktor lingkungan sesuai dengan yang disukai ikan yang menjadi sasaran penangkapan, karena ketersediaan banyak makanan yang cukup bagi ikan [2]. Sehingga, kelimpahan berbagai jenis ikan pelagis kecil, terutama ikan pemakan plankton (planktivor) secara langsung dipengaruhi oleh ketersediaan plankton di suatu perairan [3].

Plankton merupakan organisme akuatik yang berperan penting dalam menjaga keseimbangan ekosistem di laut. Plankton terdiri dari fitoplankton dan zooplankton. Menurut [1], fitoplankton merupakan pangkal mata rantai di tropic level teratas. Oleh karenanya menurut [4], sebagai produsen primer, fitoplankton akan dapat dimanfaatkan oleh zooplankton dan selanjutnya oleh ikan dan biota pemakan plankton. Sehingga plankton dapat digunakan sebagai bioindikator kesuburan perairan [5]. Pada gilirannya tingkat kesuburan perairan dapat digunakan sebagai salah satu parameter untuk memprediksi daerah penangkapan (fishing ground) [6]. Selain sebagai indikator kesuburan peraiaran, plankton juga berfungsi sebagai indikator kualitas perairan [7].

Pemantauan kualitas suatu perairan dengan pengukuran indikator biologi secara terus-menerus merupakan sebagai salah satu upaya yang mudah dan murah [8]. Sejumlah penelitian tentang indikator biologi, seperti misalnya struktur komunitas plankton dan berbagai faktor lingkungan oseanografinya telah banyak dilakukan di berbagai perairan di Indonesia, namun penelitian terkait untuk daerah penangkapan di Perairan Malang Selatan masih sangat terbatas [9]-[11]. Untuk itu, maka perlu dilakukan studi tentang variasi komunitas plankton dan hubungannya dengan parameter oseanografi, serta distribusi spasial plankton di Perairan Malang Selatan, Jawa Timur. Penelitian ini diharapkan dapat memberikan informasi penting dalam sektor perikanan di Perairan Malang Selatan.

\section{METODE PENELITIAN}

Penelitian ini dilakukan pada bulan April 2016 di daerah penangkapan di Perairan Malang Selatan yang terletak pada koordinat $8,45468^{\circ}-8,457127^{\circ} \mathrm{LS}$ dan $112,73119^{\circ}-$ $112,829071^{\circ} \mathrm{BT}$. Penentuan lokasi sampling digunakan metode purposive sampling, dan pengambilan data dilakukan dengan metode zigzag pada 10 titik sampling (titik 1 sampai 10, Gambar 1) yang mewakili kondisi lingkungan penelitian untuk mendapatkan gambaran tentang variasi komunitas plankton yang ditunjukkan dengan karakter kelimpahan, keanekaragaman, keseragaman, dominansi, jenis, serta distribusinya.

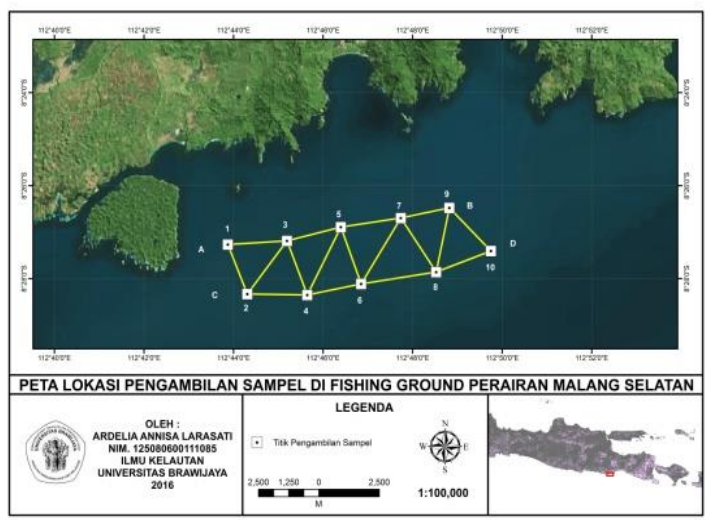

Gambar 1. Peta lokasi penelitian. 10 titik pengambilan sampel di Perairan Malang Selatan, yang diambil dengan metode zigzag.

Sampel plankton (fitoplankton dan zooplankton) diambil dengan menggunakan jaring plankton dengan meshsize $20 \mu \mathrm{m}$, pada kedalaman 1 dan $15 \mathrm{~m}$ pada 10 titik sampling. Kemudian, sampel plankton segera diawetkan pada cairan lugol $1 \%$. Pengamatan dan perhitungan kelimpahan plankton dilakukan di laboratorium hidrologi Fakultas Perikanan dan Ilmu Kelautan, Universitas Brawijaya, Malang dengan menggunakan sedgwick rafter counting cell. Identifikasi fitoplankton dan zooplankton mengacu pada buku identifikasi [12], [13]. Indeks biologi berupa kelimpahan jenis plankton dihitung berdasarkan persamaan menurut [14], indeks ekologi 
berupa indeks keanekaragaman (ShanonWiener/ H'), keseragaman (Evenness Index/ E), dan dominansi (Simpson's Index/ D) [15]. Parameter oseanografi seperti suhu, turbiditas, salinitas, DO, pH, dan klorofil-a diukur secara in situ dengan menggunakan AAQ $1183 \mathrm{C}$. Sedangkan sampel nitrat dan fosfat dianalisis di laboratorium. Semua data diplotkan secara spasial dengan menggunakan Surver. Hubungan antara parameter oseanografi dan kelimpahan plankton dianalisis dengan menggunakan Principal Component Analysis (PCA), selanjutnya uji-t digunakan untuk mengetahui adanya perbedaan antara distribusi spasial plankton di permukaan $(1 \mathrm{~m})$ dan kedalaman $15 \mathrm{~m}$.

\section{HASIL DAN PEMBAHASAN}

\section{Parameter oseanografi}

Hasil pengukuran parameter oseanografi pada kedalaman $1 \mathrm{~m}$ dan $15 \mathrm{~m}$, baik secara in situ maupun analisis di laboratorium, disajikan pada Tabel 1. Rata-rata suhu perairan pada 10 titik sampling menunjukkan suhu yang relatif rendah, yaitu sekitar antara $29,36 \pm 0,56^{\circ} \mathrm{C}$ pada permukaan dan $28,96 \pm$ $0,78^{\circ} \mathrm{C}$ pada kedalaman $15 \mathrm{~m}$. Arus bergerak ke arah timur dengan kecepatan kurang dari $0,10 \mathrm{~m} / \mathrm{s}$ (Gambar 2). Pola arus di Perairan
Malang Selatan ini mengikuti pola arus, Arus Jawa Selatan (South Java Current/ SJC), yang mempunyai pola sama sepanjang tahun. Selain itu pola arus ini juga dimodifikasi oleh arus Ekman dan gelombang Kelvin [16]. Suhu berperan penting pada organisme di laut karena dapat mempengaruhi proses fotosintesis di laut baik secara langsung maupun tidak langsung. Pengaruh langsung yaitu dalam reaksi kimia enzimatik yang berperan dalam proses fotosintesis, sedangkan pengaruh tidak langsung yaitu dapat mempengaruhi struktur hidrologi suatu perairan dimana fitoplankton itu hidup [11]. Menurut [10], kelimpahan fitoplankton tinggi terjadi pada saat suhu perairan relatif rendah antara yaitu $28-29^{\circ} \mathrm{C}$. Perairan Malang Selatan yang dengan nilai nitrat tertinggi 1,64 $\mathrm{mg} / \mathrm{L}$ dan suhu cenderung rendah $29,36{ }^{\circ} \mathrm{C}$.

Kadar oksigen terlarut pada kedalaman 1 $\mathrm{m}$ dan $15 \mathrm{~m}$ tinggi masing - masing 6,50 \pm $0,09 \mathrm{mg} / \mathrm{L}$ dan $6,57 \pm 0,26 \mathrm{mg} / \mathrm{L}$. Hal ini diduga karena adanya difusi oksigen dari udara dan besarnya sumbangan oksigen dari hasil fotosintesis oleh fitoplankton. Menurut [17], bahwa sumber utama oksigen dalam perairan adalah dari proses fotosintesis. Semakin subur suatu perairan akan semakin banyak fitoplankton yang hidup di dalamnya dan akhirnya akan meningkatkan pasokan oksigen terlarut dalam air.

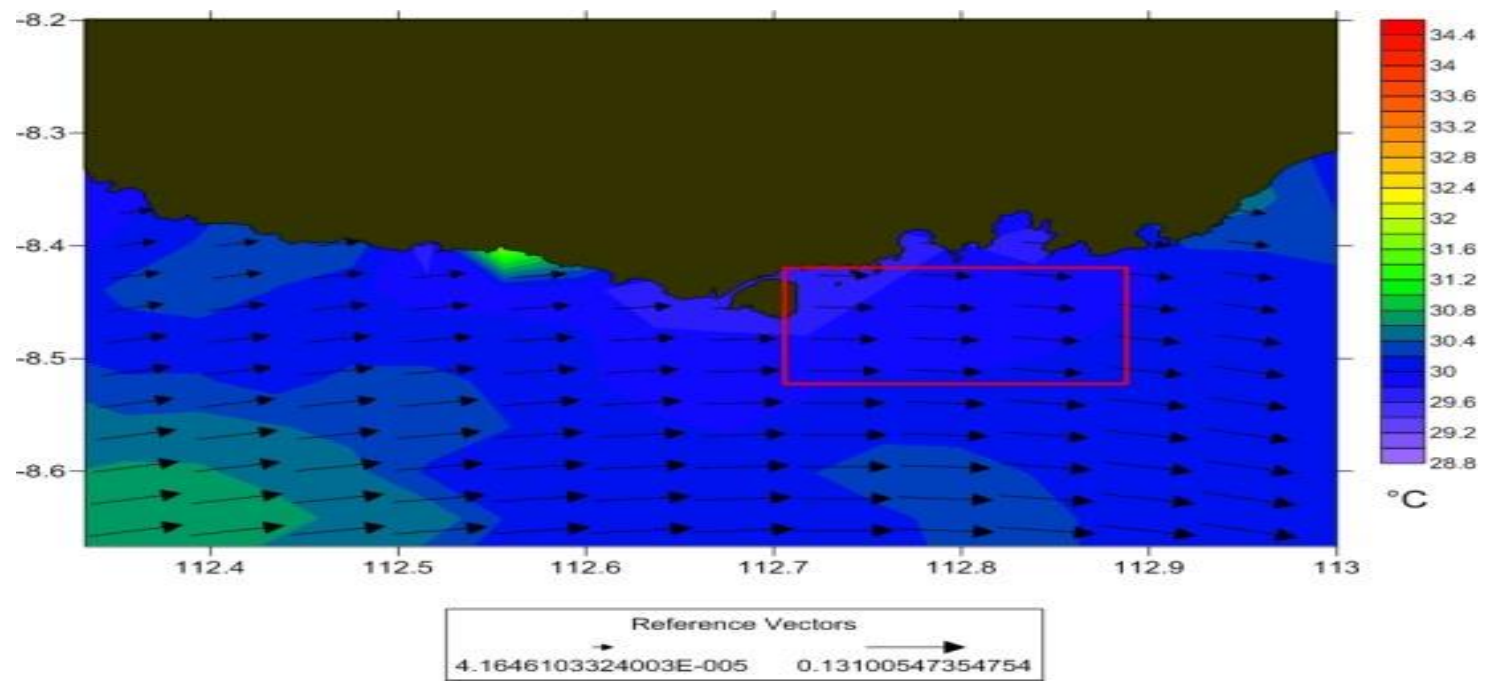

Gambar 2. Pola pergerakan arus permukaan (anak panah) dan Suhu permukaan laut (SST, skala warna) pada bulan April 2016. 
Nilai $\mathrm{pH}$ air laut pada pengamatan tidak menunjukkan adanya perbedaan yang terlalu nyata dimana rata - rata $\mathrm{pH}$ perairan adalah $8,35 \pm 0,02$ pada kedalaman $1 \mathrm{~m}$ dan $8,38 \pm$ 0,02 pada kedalaman $15 \mathrm{~m}$. Nilai $\mathrm{pH}$ Perairan Malang Selatan tergolong basa. $\mathrm{pH}$ di perairan laut umumnya berkisar antara $8,1-8,3$ pada lapisan permukaan, sedangkan pada perairan yang lebih dalam dimana kandungan oksigen lebih rendah, nilai $\mathrm{pH}$ umumnya 7,5 [18]. Hal ini dimungkinkan karena adanya pengaruh dari aktivitas biologis seperti fotosintesis dan respirasi organisme, hal tersebut sesuai dengan hasil korelasi $\mathrm{pH}$ dan oksigen terlarut pada kedalaman $15 \mathrm{~m}$, nilai $\mathrm{pH}$ berkorelasi positif dimana $\mathrm{pH}$ tinggi seiring dengan meningkatnya kandungan oksigen terlarut.

Tabel 1. Nilai rata-rata parameter Oseanografi pada 10 titik sampling.

\begin{tabular}{|c|c|c|}
\hline Parameter & $\begin{array}{c}\text { Kedalaman } \\
(\mathrm{m})\end{array}$ & Nilai \\
\hline Suhu $\left({ }^{\circ} \mathrm{C}\right)$ & 1 & $29,36 \pm 0,56$ \\
\hline $\begin{array}{c}\text { Turbiditas } \\
(\mathrm{NTU})\end{array}$ & 15 & $0,96 \pm 0,78$ \\
\hline $\begin{array}{c}\text { Salinitas } \\
(\% \mathrm{o})\end{array}$ & $15 \pm 0,08$ \\
\hline $\mathrm{DO}(\mathrm{mg} / \mathrm{L})$ & 15 & $33,22 \pm 0,06$ \\
\hline $\mathrm{pH}$ & 15 & $33,70 \pm 0,07$ \\
\hline $\begin{array}{c}\mathrm{Klorofil-a} \\
\left(\mathrm{mg} / \mathrm{m}^{3}\right)\end{array}$ & 1 & $6,50 \pm 0,09$ \\
\hline $\begin{array}{c}\text { Nitrat } \\
(\mathrm{mg} / \mathrm{L})\end{array}$ & 1 & $8,35 \pm 0,26$ \\
\hline $\begin{array}{c}\text { Fosfat } \\
(\mathrm{mg} / \mathrm{L})\end{array}$ & 1 & $0,38 \pm 0,02$ \\
\hline
\end{tabular}

Klorofil-a hasil pengukuran in situ menunjukkan nilai rendah pada kedua kedalaman 1 dan $15 \mathrm{~m}$, secara berturut-turut yaitu $0,24 \pm 0,05 \mathrm{mg} / \mathrm{m}^{3}$ dan $0,36 \pm 0,08$ $\mathrm{mg} / \mathrm{m}^{3}$. Rendahnya konsentrasi klorofil-a pada bulan April ini umum terjadi pada musim Peralihan I (Maret, April, Mei) di Perairan Selatan Jawa dan Bali, yang masih dipengaruhi oleh musim barat [19], [20].
Kadar nitrat dan fosfat pada kedalaman 1 $\mathrm{m}$ relatif tinggi yaitu $1,27 \pm 0,00 \mathrm{mg} / \mathrm{L}$ dan $0,26 \pm 0,00 \mathrm{mg} / \mathrm{L}$. Menurut [21], fitoplankton dapat tumbuh dengan baik pada konsentrasi nitrat $0,5-2 \mathrm{mg} / \mathrm{L}$ dan fosfat $0,01-0,1 \mathrm{mg} / \mathrm{L}$. Lebih jauh [11] menyatakan bahwa perairan perairan yang terdapat upwelling adalah merupakan perairan yang kaya akan nutrien dan tingkat kesuburannya tinggi.

\section{Fitoplankton dan Zooplankton}

Hasil penelitian ini ditemukan sebanyak total 42 genus fitoplankton pada kedalaman 1 $\mathrm{m}$ dan $15 \mathrm{~m}$ (Tabel 2). Pada kedalama $1 \mathrm{~m}$ ditemukan 39 genus termasuk dalam 5 kelas yaitu Bacillariophyceae (27 genus), Chlorophyceae (3 genus), Chrysophyceae (1 genus), Cyanophyceae (2 genus), dan Dinophyceae (6 genus). Sedangkan pada kedalaman $15 \mathrm{~m}$, ditemukan 35 genus terdiri dari 25 genus kelas Bacillariophyceae, 5 genus kelas Dinophyceae, 2 genus kelas Cyanophyceae, 2 genus kelas Chlorophyceae, dan 1 genus kelas Chrysophyceae. Kelimpahan total fitoplankton antara 183 $7.841 \mathrm{sel} / \mathrm{m}^{3}$ dengan total kelimpahan sebesar $49.764 \mathrm{sel} / \mathrm{m}^{3}$. Kelas Bacillariophyceae atau diatom di kedalaman $1 \mathrm{~m}$ dan $15 \mathrm{~m}$ mencapai 91 dan $92 \%$ dari total jenis kelimpahan fitoplankton dengan nilai masing - masing $42.351 \mathrm{sel} / \mathrm{m}^{3}$ dan $2.819 \mathrm{sel} / \mathrm{m}^{3}$. Kelas Bacillariophyceae merupakan kelas yang dominan ditemukan dari total jenis dibandingkan dengan kelas fitoplankton lainnya yang cukup sering dijumpai pada beberapa perairan laut. Tingginya Bacillariophyceae juga ditemukan di Selat Bali [10]; di perairan Selatan Jawa Timur, Lombok dan perairan Bali [11]; Kepulauan Seribu [18]; dan Teluk Jakarta [7]. Beberapa genus dari kelas Bacillariophyceae seperti Chaetoceros sp., Bacteriastrum sp., Nitzschia sp., dan Leptocylindrus sp. memiliki frekuensi kemunculan dan kelimpahan yang cukup tinggi secara umum pada semua titik pengamatan. Menurut [11], jenis fitoplankton dari kelas Bacillariophyceae sering dijadikan sebagai indikator kesuburan perairan. 
Tabel 2. Kelimpahan Fitoplankton $\left(\mathrm{sel} / \mathrm{m}^{3}\right)$ pada Kedalaman $1 \mathrm{~m}$ dan $15 \mathrm{~m}$ di Perairan Malang Selatan

\begin{tabular}{|c|c|c|c|}
\hline Genus & Kelas & N-1 m & $\mathrm{N}-15 \mathrm{~m}$ \\
\hline Amphora sp. & Bacillariophyceae & 3 & - \\
\hline Asterionella sp. & Bacillariophyceae & 391 & 29 \\
\hline Bacteriastrum sp. & Bacillariophyceae & 7636 & 307 \\
\hline Biddulphia sp. & Bacillariophyceae & 32 & 2 \\
\hline Cerataulina sp. & Bacillariophyceae & 111 & 3 \\
\hline Ceratocorys sp. & Bacillariophyceae & 14 & 1 \\
\hline Chaetoceros sp. & Bacillariophyceae & 21065 & 1498 \\
\hline Climacodium sp. & Bacillariophyceae & - & 1 \\
\hline Corethron sp. & Bacillariophyceae & 51 & 4 \\
\hline Coscinodiscus sp. & Bacillariophyceae & 309 & 23 \\
\hline Ditylum sp. & Bacillariophyceae & 44 & 3 \\
\hline Eucampia sp. & Bacillariophyceae & 16 & - \\
\hline Gonyaulax sp. & Bacillariophyceae & 92 & 6 \\
\hline Guinardia sp & Bacillariophyceae & 38 & 4 \\
\hline Gyrosigma sp. & Bacillariophyceae & 6 & - \\
\hline Hemiaulus sp. & Bacillariophyceae & 350 & 25 \\
\hline Leptocilyndrus sp. & Bacillariophyceae & 3086 & 228 \\
\hline Leucosolenia sp. & Bacillariophyceae & 6 & - \\
\hline Licmophora sp. & Bacillariophyceae & 10 & - \\
\hline Navicula sp. & Bacillariophyceae & 1 & - \\
\hline Nitzschia sp. & Bacillariophyceae & 4021 & 286 \\
\hline Pleurosigma sp. & Bacillariophyceae & 91 & 2 \\
\hline Rhabdonema sp. & Bacillariophyceae & - & 1 \\
\hline Rhizosolenia sp. & Bacillariophyceae & 2339 & 222 \\
\hline Sticholonche sp. & Bacillariophyceae & 2060 & 125 \\
\hline Surirella sp. & Bacillariophyceae & 6 & 1 \\
\hline Synedra sp. & Bacillariophyceae & 5 & - \\
\hline Thalassionema sp. & Bacillariophyceae & 320 & 25 \\
\hline Thalassiothrix sp. & Bacillariophyceae & 250 & 24 \\
\hline Acanthosphaera sp. & Chlorophyceae & 3 & - \\
\hline Closterium sp. & Chlorophyceae & 29 & 3 \\
\hline Volvox sp. & Chlorophyceae & 7 & - \\
\hline Distephanus sp. & Chrysophyceae & 1 & - \\
\hline Oscillatoria sp & Cyanophyceae & 3683 & 218 \\
\hline Spirulina sp. & Cyanophyceae & 2 & - \\
\hline Ceratium sp. & Dinophysis & 332 & 17 \\
\hline Dinophysis sp. & Dinophysis & 52 & 1 \\
\hline Orinthocercus sp. & Dinophysis & 5 & - \\
\hline Peridinium sp. & Dinophysis & 40 & 9 \\
\hline Protoperidinium sp. & Dinophysis & 185 & - \\
\hline Pyrophacus sp. & Dinophysis & 5 & - \\
\hline Phalacroma sp. & Dinophysis & - & - \\
\hline
\end{tabular}


Distribusi kelimpahan fitoplankton ditunjukkan oleh adanya degradasi warna pada kedua kedalaman, $1 \mathrm{~m}$ dan $15 \mathrm{~m}$ (Gambar 3) yang menunjukkan bahwa kelimpahan fitoplankton pada kedalaman $1 \mathrm{~m}$ lebih melimpah dibandingkan di kedalaman $15 \mathrm{~m}$. Kelimpahan fitoplankton yang tinggi $\left(>5.000 \mathrm{sel} / \mathrm{m}^{3}\right)$ ditemukan di sebelah utara dan semakin menurun $\left(2.000 \mathrm{sel} / \mathrm{m}^{3}\right) \mathrm{ke}$ arah tengah perairan, namun cenderung naik lagi ke arah barat perairan $\left(4000-7000 \mathrm{sel} / \mathrm{m}^{3}\right)$. Kelimpahan fitoplankton yang rendah di kedalaman 15 m dikarenakan pada pagi hari dimana masih terdapat intensitas cahaya matahari yang optimal bagi plankton untuk berfotosintesis, sehingga fitoplankton tidak jauh dari permukaan, namun pada beberapa titik pengambilan sampel, kelimpahan fitoplankton rendah. Hal tersebut dimungkinkan adanya grazing oleh zooplankton. Menurut [22], hubungan fitoplankton dan zooplankton dapat berupa osilasi yaitu mangsa dan pemangsa atau grazing. Pada waktu tertentu terjadi time lag dimana fitoplankton tidak melimpah, dikarenakan munculnya zooplankton yang lebih dominan.

Penelitian ini dilakukan pada bulan April yang masuk pada musim peralihan I (Maret, April, Mei), dapat dikatakan masih terpengaruh oleh musim Barat (Desember, Januari, Februari) [9], [20], fitoplankton mulai menurun dan diikuti dengan tumbuhnya zooplankton baik jumlah maupun jenisnya. Menurut [10], terdapat perbedaan kecepatan tumbuh antara fitoplankton dengan zooplankton, dimana fitoplankton tumbuh dengan mengalami pembelahan lebih cepat daripada siklus reproduksi zooplankton.

Hasil uji statistik terhadap kelimpahan fitoplankton antara kedalaman $1 \mathrm{~m}$ dan $15 \mathrm{~m}$ menunjukkan bahwa $\mathrm{T}_{\text {hitung }}>\mathrm{T}_{\text {tabel }}$ yaitu 6,957 $>1,746$. Hal ini menunjukkan kelimpahan fitoplankton pada dua kedalaman di daerah penangkapan ikan tersebut berbeda, yaitu distribusi kelimpahan di kedalaman $1 \mathrm{~m}$ lebih tinggi dibandingkan dengan kelimpahan di kedalaman $15 \mathrm{~m}$. Hal ini dikarenakan pada permukaan masih banyak dipengaruhi oleh proses fotosintesis, dari pada di kedalam $15 \mathrm{~m}$.

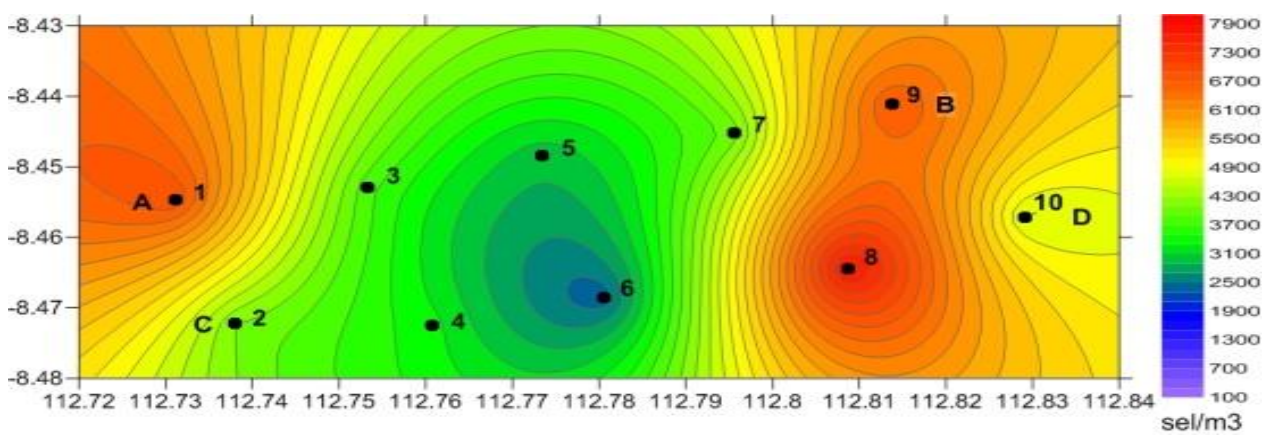

(B)

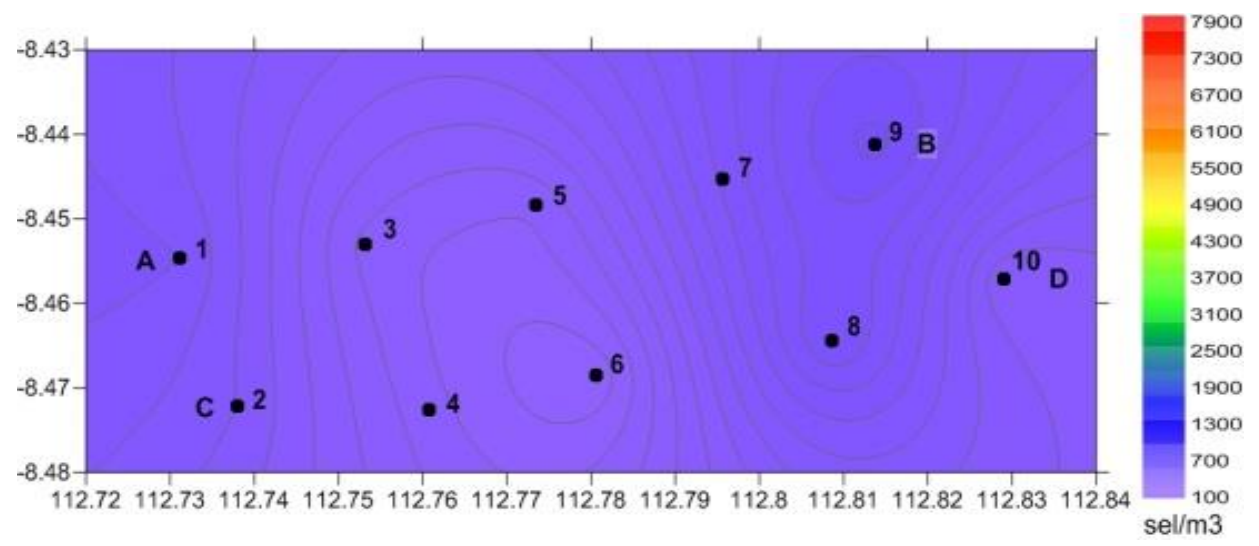

Gambar 3. Distribusi kelimpahan fitoplankton di kedalaman $1 \mathrm{~m}$ (A) dan 15 m (B). 
Distribusi kelimpahan zooplankton disajikan pada Gambar 4. Perbedaan gradasi warna di kedua kedalaman, $1 \mathrm{~m}$ dan $15 \mathrm{~m}$ menunjukkan bahwa pada kedalam $1 \mathrm{~m}$ kelimpahannya lebih tinggi daripada pada kedalam $15 \mathrm{~m}$. Zooplankton ditemukan total sebanyak 21 genus pada semua kedalaman. Pada kedalaman $1 \mathrm{~m}$ ditemukan 18 genus, termasuk dalam 6 kelas yaitu Copepoda $(7$ genus), Ciliata (7 genus), Granuloreticulosa (1 genus), Polychaeta (1 genus), Appendicularia (1 genus) dan Ophiuroidae (1 genus) dan pada kedalaman $15 \quad \mathrm{~m} \quad 17$ genus dimana komposisinya adalah 9 genus kelas Copepoda, 6 genus kelas Ciliata, 1 genus kelas Granuloreticulosa dan 1 genus kelas Appendicularia. Hasil penelitian menunjukkan kelimpahan zooplankton antara $6-115$ $\mathrm{ind} / \mathrm{m}^{3}$ dengan total kelimpahan zooplankton sebesar $894 \mathrm{ind} / \mathrm{m}^{3}$. Kelas Copepoda di kedalaman $1 \mathrm{~m}$ dan $15 \mathrm{~m}$ mencapai 58\% dan $63 \%$ dari total jenis kelimpahan zooplankton dengan nilai masing - masing $469 \mathrm{ind} / \mathrm{m}^{3}$ dan $47 \mathrm{ind} / \mathrm{m}^{3}$. Distribusi kelimpahan zooplankton (Gambar 4) menunjukkan bahwa zooplankton lebih melimpah pada kedalaman $1 \mathrm{~m}$ dibandingkan kedalaman $15 \mathrm{~m}$. Dari pola distribusi zooplankton juga tidak terpola dengan teratur dan mirip dengan pola distribusi fitoplankton dengan nilai koefisien kelimpahannya yang tinggi $\left(116 \mathrm{ind} / \mathrm{m}^{3}\right)$ dan rendah (> $6 \mathrm{ind} / \mathrm{m}^{3}$ ). Menurut [10], pengaruh dari arus dapat menyebabkan zooplankton terdistribusi tidak merata.

Nilai rata - rata indeks keanekaragaman, keseragaman dan dominansi fitoplankton pada kedalaman $1 \mathrm{~m}$ diketahui masing - masing sebesar 1,$85 ; 0,59 ; 0,27$, sedangkan pada kedalaman $15 \mathrm{~m}$ berturut-turut 1,$77 ; 0,58$; 0,28 . Sedangkan pada zooplankton indeks keanekaragaman, keseragaman dan dominansi pada kedalaman $1 \mathrm{~m}$ berturut-turut 1,$77 ; 0,79$; 0,24, dan pada kedalaman $15 \mathrm{~m}$ berturut-turut 1,$70 ; 0,77 ; 0,27$. Berdasarkan hasil tersebut dapat disimpulkan bahwa keanekaragaman plankton dapat dikategorikan sedang yang ditunjukkan dengan nilai keanekaragaman 13. Keseragaman sedang dengan nilai rata-rata $0,4 \leq 0,6$ dan dominansi rendah dengan nilai rata-rata kurang dari 1 .

Hasil uji statistik menunjukkan bahwa kelimpahan zooplankton pada daerah penangkapan berbeda antara kedalaman $1 \mathrm{~m}$ dan $15 \mathrm{~m}$, dimana $\mathrm{T}_{\text {hitung }}>\mathrm{T}_{\text {tabel }}$ yaitu 11,019 $>1,746$.

(A)

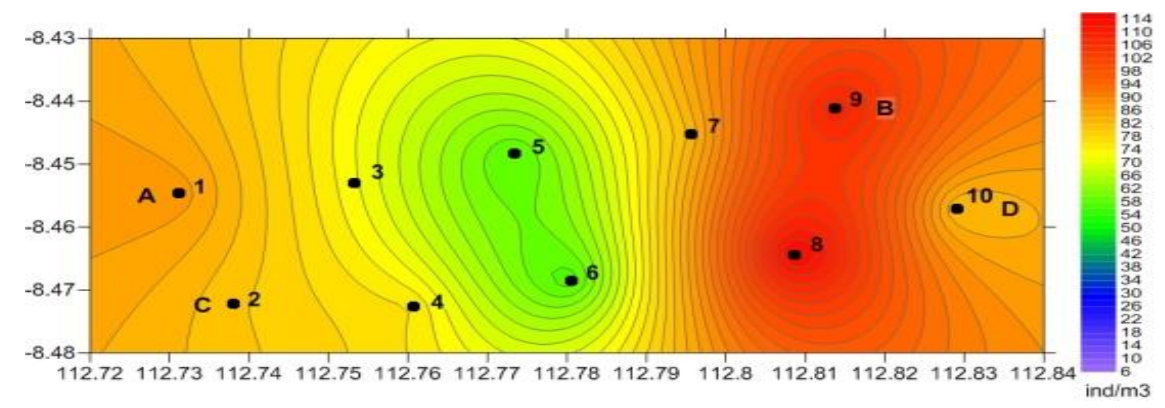

(B)

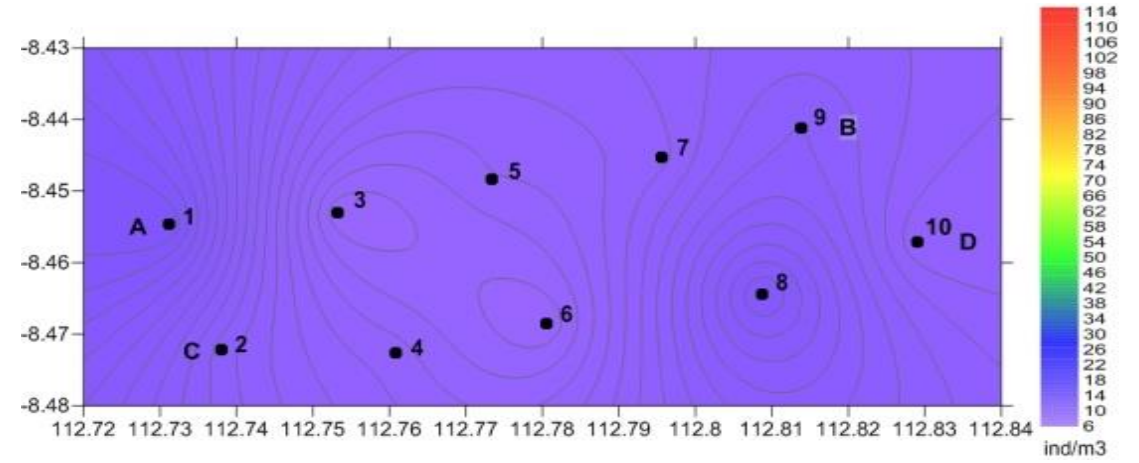

Gambar 4. Distribusi kelimpahan zooplankton di kedalaman 1 m (A) dan 15 m (B) 


\section{Hubungan struktur komunitas plankton dan parameter oseanografi}

Hasil korelasi pearson dari Principal Componen Analysis (PCA) menunjukkan bahwa parameter fisika-kimia pada kedalaman $1 \mathrm{~m}$ yang berkorelasi dengan struktur komunitas fitoplankton adalah turbiditas dan klorofil-a, sedangkan parameter oseanografi yang berkorelasi dengan struktur komunitas zooplankton adalah turbiditas, klorofil-a, oksigen terlarut dan fosfat. Hubungan korelasi ditunjukkan pada Tabel 3.

Hubungan sangat erat ditunjukkan antara klorofil-a dan kelimpahan fitoplankton, yang mengindikasikan adanya kelimpahan klorofila tergantung pada kelimpahan fitoplankton di suatu perairan, sesuai dengan pernyataan [23]. Selain itu tinggi rendahnya turbiditas tergantung pada intensitas cahaya matahari yang masuk ke perairan, dimana jika turbiditas rendah maka cahaya matahari yang masuk ke perairan akan lebih optimal dan akan dimanfaatkan fitoplankton untuk berfotosintesis.

Factor loading pada analisis PCA menunjukkan bahwa parameter utama (F1) yang mempengaruhi kelimpahan plankton adalah turbiditas, oksigen terlarut (DO), klorofil-a (Chl-a) dan fosfat (Tabel 4). Nilai ini seiring dengan hasil korelasi Pearson, dimana struktur komunitas plankton sangat dipengaruhi oleh turbiditas, oksigen terlarut, klorofil-a dan fosfat. Menurut [24], hasil faktor loading tipe 1 (faktor utama) pada distribusi plankton menunjukkan korelasi positif antara kelimpahan dan klorofil-a.

Hasil korelasi dan factor loading membuktikan bahwa keberadaan plankton (fitoplankton dan zooplankton) di suatu perairan sangat dipengaruhi oleh parameter oseanografi baik pengaruh secara langsung maupun tidak langsung

Tabel 3. Korelasi Pearson antara Kelimpahan Plankton dengan Parameter Fisika-Kimia

\begin{tabular}{lrrrrrrrrrr}
\hline Variables & \multicolumn{1}{c}{ Fito } & \multicolumn{1}{c}{$\begin{array}{c}\text { Z } \\
\text { Zoo }\end{array}$} & Suhu & $\begin{array}{c}\text { Turbi- } \\
\text { ditas }\end{array}$ & $\begin{array}{c}\text { Salini } \\
\text {-tas }\end{array}$ & pH & DO & Chl-a & Nitrat & $\begin{array}{c}\text { Fos- } \\
\text { fat }\end{array}$ \\
\hline N Fito & 1 & & & & & & & & & \\
N Zoo & 0.919 & 1 & & & & & & & & \\
Suhu & 0.028 & 0.044 & 1 & & & & & & & \\
Turbuditas & 0.836 & 0.9 & 0.09 & 1 & & & & & & \\
Salinitas & 0.073 & -0.089 & -0.293 & -0.016 & 1 & & & & & \\
pH & -0.298 & -0.095 & -0.082 & -0.271 & -0.232 & 1 & & & & \\
DO & 0.612 & 0.653 & 0.269 & 0.531 & -0.696 & -0.232 & 1 & & & \\
Chl-a & 0.862 & 0.865 & -0.188 & 0.857 & 0.349 & -0.274 & 0.278 & 1 & & \\
Nitrat & 0.276 & -0.059 & -0.117 & -0.01 & 0.556 & -0.485 & -0.277 & 0.237 & 1 & \\
Fosfat & -0.432 & -0.663 & -0.246 & -0.625 & 0.444 & 0.072 & -0.565 & -0.49 & 0.453 & 1 \\
\hline
\end{tabular}

Tabel 4. Factor loading Parameter Oseanografi dan Struktur Komunitas Plankton pada Kedalaman $1 \mathrm{~m}$.

\begin{tabular}{lrrrrr}
\hline & \multicolumn{1}{c}{ F1 } & \multicolumn{1}{c}{ F2 } & \multicolumn{1}{c}{ F3 } & \multicolumn{1}{c}{ F4 } & \multicolumn{1}{c}{ F5 } \\
\hline N Fito & 0.912 & 0.287 & -0.037 & -0.010 & 0.272 \\
N Zoo & 0.966 & 0.036 & 0.193 & 0.042 & 0.135 \\
Suhu & 0.127 & -0.421 & -0.543 & 0.710 & 0.077 \\
Turbuditas & 0.931 & 0.117 & 0.082 & 0.102 & -0.083 \\
Salinitas & -0.171 & 0.880 & 0.224 & 0.312 & -0.092 \\
pH & -0.297 & -0.352 & 0.742 & 0.259 & 0.391 \\
DO & 0.725 & -0.486 & -0.273 & -0.281 & 0.256 \\
Chl-a & 0.841 & 0.470 & 0.230 & 0.052 & -0.110 \\
Nitrat & -0.032 & 0.821 & -0.436 & -0.013 & 0.212 \\
Fosfat & -0.731 & 0.443 & -0.121 & -0.101 & 0.407 \\
\hline
\end{tabular}




\section{KESIMPULAN}

Berdasarkan tinjauan struktur komunitas plankton, perairan yang diamati dalam keadaan subur dengan kelimpahan fitoplakton sebesar $49.764 \mathrm{sel} / \mathrm{m}^{3}$, dominasi genus Chaetoceros sp. (Bacillariophyceae) dan kelimpahan zooplankton $894 \mathrm{ind} / \mathrm{m}^{3}$, dominasi genus Nauplius sp. (Copepoda). Demikian halnya dengan kondisi perairan yang secara ekologis berada dalam keadaan yang cukup stabil. Hal ini dicirikan dengan tidak adanya dominansi jenis oleh plankton tertentu. Berdasarkan analisis PCA, parameter utama yang paling berpengaruh terhadap struktur komunitas plankton yaitu turbiditas,DO, klorofil-adan fosfat. Distribusi spasial plankton berdasarkan kelimpahan plankton di kedalaman $1 \mathrm{~m}$ dan $15 \mathrm{~m}$ berbeda.

\section{UCAPAN TERIMAKASIH}

Ucapan terimakasih disampaikan kepada semua pihak yang membantu terlaksananya penelitian ini. Penelitian ini merupakan bagian dari penelitian Nomor 137/SP2H/LT/DRPM/ III/2016, tanggal 10 Maret 2016.

\section{DAFTAR PUSTAKA}

[1] D. Hermawan. Prospektif Pengembangan Kawasan Pesisir Sendang Biru untuk Industri Perikanan Terpadu. Prospektif Pengembangan Kawasan Pesisir Sendang Biru. Vol. 13.No. 2. 2006.

[2] T. S. H. Djumanto, Pontororing, dan L. Reinhard. Pola Sebaran Horizontaldan Kerapatan Plankton di Perairan Bawean. J. Perikan. XI (1): 115-122. 2009.

[3] A. A. Hickman, P. M. Holligan, C. Mark Mooreet, J. Shar ples, V. Krivtsov \& M.R. Palmer. Distribution and chromatic adaptation of phytoplankton within a shelf sea thermocline. Limnol. Oceanogr., 54(2), 525-536. 2009.

[4] M. Simanjuntak. Hubungan Faktor Lingkungan Kimia, Fisika Terhadap Distribusi Plankton di Perairan Belitung
Timur, Bangka Belitung. J. Perikan. No. XI (1). Hal: 31-45. 2009.

[5] S. Haumahu. Distribusi Spasial Fitoplankton di Perairan Teluk Haria Saparua, Maluku Tengah. J. Ilmu Kelaut., Vol.10 (3). Hal:126-134. 2005.

[6] Yuliana, E. M. Adiwilaga, E. Harris, dan N. T. M. Pratiwi. Hubungan Antara Kelimpahan Fitoplankton dengan Parameter Fisika-Kimiawi Perairan di Teluk Jakarta. Akuatik,. 3 (2):169-179. 2012.

[7] Kasma, E., T. Osawa, dan I. W. S. Adnyana. Estimation of Primary Productivity For Tuna in Indian Ocean. Ecotrophioc, 4 (2) : 86-91. 2007

[8] Y. Utomo, Priyono, B., Ngabekti, S. Saprobitas Perairan Sungai Juwana Berdasarkan Bioindikator Plankton. Unnes L. Life Sci 2. 2013.

[9] A. Sartimbul, D. C. Pratiwi, A. Yamindago., E. Rohadi., dan R.I. Khasanah. Variasi Spasial Plankton Sebagai Respon Terhadap Perubahan Iklim di Pantai Jawa Timur. Seminar Nasional Perikanan dan Kelautan V. Universitas Brawijaya. 2015.

[10] R. I. Khasanah, A. Sartimbul, dan E.Y. Herawati. Kelimpahan dan Keanekaragaman Plankton di Perairan Selat Bali. J. Ilmu Kelaut., Vol.18 (4). Hal: 193-202. 2013.

[11] I. S. Sachoemar, dan N. Hendiarti. Struktur Komunitas dan Keragaman Plankton Antara Perairan Laut di Selatan Jawa Timur, Bali dan Lombok. J. Hidrosfir. Vol.1. No.1. Hal: 21-26 . 2006.

[12] I. Yamaji. The plankton of Japanese Coastal Waters. 238p. 1974.

[13] A. Shirota. Plankton. Overseas Technology Corporation Agency. Hal: 489. 1966. 
[14] APHA (American Public Health Association). Standard Methods for the Examination of Water and Waste Water Including Bottom Sediment and Sludges. 17th ed. Am. Public Health Assoc., Inc., New York. 1527 p. 1989.

[15] E. P. Odum. Fundamentals of Ecology. 3rd ed. W. B. Saunders Company. Philadelphia. 1971.

[16] J. Sprintall, S. Wijffels, R. Molcard, I. Jaya. Direct evidence of the South Java Current system in Ombai Strait. Dinamics of Atmospheres and Oceans, 50-2, P 140-156. 2010.

[17] H. Effendi. Telaah Kualitas Air bagi Pengelolaan Sumberdaya dan Lingkungan Perairan. Kanisius, Yogyakarta. 2003.

[18] A. Asmara. Hubungan Struktur Komunitas Plankton dengan Kondisi Fisika-Kimia Perairan Pulau Pramuka dan Pulau Panggang, Kepulauan Seribu. Bogor Agricultural University. 2005.

[19] N. Hendiarti, Suwarso, Aldrian, E., Amri, K., Andiastuti, R., Sachoemar, I., Wahyono, I.B. Seasonal variation of pelagic fish catch around Java. In: The Indonesian Sea. Oceanogr. I 18:4, 113123. 2005 .
[20] A. Sartimbul, H. Nakata., E. Rohadi, B. Yusuf., dan H.P. Kadarisman. Variations in chlorophyll-a concentration and the impact on Sardinella lemuru catches in Bali Strait Indonesia, Progess In Oceanography87 (2010) halaman 168174. 2010.

[21] R. E. Hecky, dan P. Kilham. Nutrient limitation of Phytoplankton in freshwater and marine environemnts: a review of recent evidencence on the effect of enrichemnet. Limnol. Oceanogr., 33:796822. 1988.

[22] O. Larink,dan Wilfried W. 2006. Coastal Plankton: Photo Guide for European Seas. AWI. Munchen

[23] N. Fitriya, H. Surbakti, R. Aryawati. Pola sebaran plankton serta klorofil-a pada bulan Nopember di Perairan Tambelan, Laut Natuna. Maspari J., Vol. 03. Hal: 01-08. 2011.

[24] J. H. Kang, Woong S. K., Kyung I. C . dan Jae H. N. 2004. Distribution of Plankton Related to theMesosclae Physical Strusture within the Surface Mixed Layer in The Southwestern East Sea, Korea. J. Plankton Res., Volume 26 No. 12. 1515-1528. 2004. 